\title{
Influence of connectivity on Cladocera diversity in oxbow lakes in the Taquari River floodplain (MS, Brazil)
}

\author{
Influência da conectividade sobre a diversidade de Cladocera em lagoas \\ marginais da planície de inundação do Rio Taquari (MS, Brasil)
}

\author{
Adriana Maria Güntzel, Eliana Aparecida Panarelli, \\ William Marcos da Silva and Kennedy Francis Roche \\ Universidade Estadual de Mato Grosso do Sul - UEMS-MS, \\ Rua General Mendes de Moraes, 370, CEP 79400-000, Coxim, MS, Brazil \\ e-mail: amguntzel@uems.br, epanarelli@ig.com.br,wmsilvax@ig.com.br, kroche@nin.ufms.br
}

\begin{abstract}
Aim: The aim of this study was evaluate the influence of river-lake connectivity on Cladocera diversity; Methods: Sampling of macrophyte stands of three oxbow lakes were carried out between August/04 and September/06 every two months; Results: A total of 49 Cladocera species were identified. Three are new records for the state. The Chydoridae family was the most representative, with 34 species. In lakes 1 and 2, Chydoridae and Macrothricidae were the most abundant taxa, while Chydoridae and Daphniidae were the most representative groups in lake 3. Abundance and species richness tended to be greater in lakes 1 and 2; Conclusions: In the oxbow lakes, the environmental variations conditioned by annual dry and rainfall cycles favored a greater diversity of Cladocera, since a greater connectivity with the Taquari River produces constant disturbances that are detrimental to the diversity of this group.
\end{abstract}

Keywords: Taquari River Basin, Nhecolândia Pantanal, aquatic communities, limnology.

Resumo: Objetivo: $\mathrm{O}$ objetivo deste estudo foi avaliar a influência da conectividade rio-lagoas marginais sobre a diversidade de Cladocera; Métodos: As amostragens foram realizadas em bancos de macrófitas de agosto/04 a setembro/06, em meses alternados; Resultados: Um total de 49 espécies de Cladocera foi identificado. Destas, três espécies são consideradas registros novos para o Estado. A família Chydoridae foi a mais representativa, com 34 espécies. Nas lagoas 1 e 2, Chydoridae e Macrothricidae foram os taxa mais abundantes, enquanto Chydoridae e Daphniidae foram os grupos mais representativos na lagoa 3. A abundância e a riqueza de espécies tenderam a ser maiores nos lagos 1 e 2; Conclusóes: As variaçóes ambientais condicionadas pelos ciclos anuais de seca e chuva favoreceram maior diversidade de Cladocera, uma vez que maior conectividade com o Rio Taquari produz distúrbios constantes que são prejudiciais à diversidade desse grupo.

Palavras-chave: Bacia Hidrográfica do Rio Taquari, Pantanal da Nhecolândia, comunidades aquáticas, limnologia.

\section{Introduction}

Oxbow lakes situated in the Pantanal floodplain are subject to unimodal and predictable flood pulses that, according to Junk and Silva (1995), are the principal forcing functions of these systems.

Oscillations in river level influence floodplain lakes in various ways, depending on the type of connection between lake and river. This connection may be temporary or permanent, according to the morphology, position and size of the lake (Junk, 1980). These characteristics also condition the structure of the macrophyte assemblages, which determine the dynamics of many limnological variables, such as nutrient and dissolved oxygen concentrations and $\mathrm{pH}$, and offer conditions for a rich and abundant invertebrate fauna (Junk, 1997).

Inventories of the invertebrates associated with macrophytes in Brazilian waters, such as those by Azevedo and Bonecker (2003), Lima et al. (2003), Serafim Jr. et al. (2003) and Alves et al. (2005), are still rare. This fact complicates the understanding of trophic relationships in macrophyte banks. This lack of information on the littoral fauna can be attributed to sampling difficulty and taxonomic problems with regard to groups such as the cladocerans (Wisniewski et al., 2000). Studies 
carried out in the Midwest region of Brazil have indicated a very high diversity of invertebrates in these habitats as compared to the open water in, for example, the Paraná River (Paggi and José de Paggi, 1990; Bonecker et al., 1994; Lima et al., 1996; Lansac-Tôha et al., 1997; Sendacz, 1997), and the southern Pantanal (Bonecker et al., 1998).

The Cladocera are an especially abundant group among the invertebrates associated with macrophytes (Rocha and Por, 1998). The objective of the present study was to expand the current knowledge on the diversity of Cladocera associated with macrophytes in oxbow lakes of the State of Mato Grosso do Sul (Brazil) and to investigate the role of the hydrologic cycle in structuring Cladocera communities in oxbow lakes of different degrees of connectivity with the river. Our hypothesis is that in floodplains, greater connectivity between oxbow lakes and the main channel of the river may result in a decrease in Cladocera diversity when associated with intense and frequent disturbance, which may be detrimental to the re-establishment of their populations.

The studied lakes are located in the Paraguay River Basin, which has been relatively neglected with respect to this type of study.

\section{Study Area}

The alluvial plain of the Taquari River, one of the main tributaries of the Pantanal (Galdino et al., 2005), is situated in the two main regions of Paiaguás and Nhecolândia. The Taquari basin occupies an area of $65,023 \mathrm{~km}^{2}$ and is characterized by an Awtype climate, according to Köeppen's classification system, corresponding to a semi-humid tropical climate, with a mean annual temperature of $26{ }^{\circ} \mathrm{C}$ and mean annual rainfall between 800 and $1600 \mathrm{~mm}$.year ${ }^{-1}$. It has two distinct seasons, wet, from October to March, and dry, from April to September.

The location of the three study lakes in the Taquari River Basin are shown in Figure 1.

\section{Methodology}

Sampling was carried out from August/04 to September/06 at a single point in the littoral region of each lake. Physical and chemical variables were obtained from Güntzel et al. (submitted). The organisms were collected in floating macrophyte stands at the surface of the lakes using a tray $(60 \times 40 \times 10 \mathrm{~cm})$. The macrophyte roots (mainly Eichhornia azurea) were washed with carbonated water to anaesthetize the organisms and the

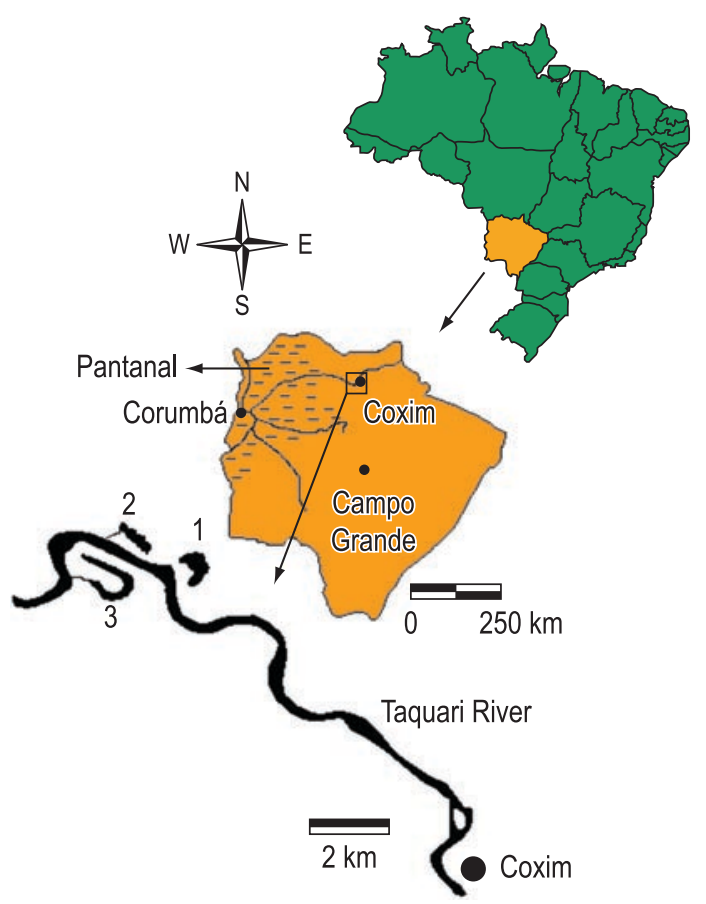

Figure 1. Study area in the Middle Taquari River Basin: Lake Buritizinho (1), Lake Ribeirão (2), Lake Deda (3).

water samples were filtered through a $50-\mu \mathrm{m}$ mesh. Fixation was done with $4 \%$ formaldehyde. Cladoceran species were identified and enumerated according to abundance of organisms in subsamples of 15 to $40 \mathrm{~mL}$.

Cluster analysis of the samples, based on Euclidean distance and UPGMA grouping methods, were carried out using the software Statistica 7.0. Species richness, the diversity index of ShannonWienner, and Pielou's Equitability (Odum, 1988) were calculated.

Pearson correlation analysis was carried out between the environmental variables (river level, rain volume, local depth, Secchi transparency, $\mathrm{pH}$, conductivity, water temperature, dissolved oxygen, total nitrogen and phosphorus, suspended organic and inorganic solids, and chlorophyll-a), and the richness and abundance of Cladocera. Hydrological and limnological variables were obtained from Güntzel et al. (submitted). Species distribution patterns in relation to environmental variables were examined using Canonical Correspondence Analysis (Braak and Verdonschot, 1995).

\section{Results}

Considering all three lakes, 49 taxa were recorded (Table 1). Chydoridae was the most representative family (34 species), followed by the Macrothricidae family (5 species). The following 
Table 1. List of Cladocera species recorded in the three lakes from September/04 to August/06. New records for the Mato Grosso do Sul State $\left(^{*}\right)$, presence $(+)$ and absence (-) of the taxa.

\begin{tabular}{|c|c|c|c|}
\hline & $\begin{array}{c}\text { Lake } \\
1\end{array}$ & $\begin{array}{l}\text { Lake } \\
2\end{array}$ & $\begin{array}{l}\text { Lake } \\
3\end{array}$ \\
\hline \multicolumn{4}{|l|}{ Ctenopoda } \\
\hline \multicolumn{4}{|l|}{ Sididae Baird, 1850} \\
\hline Diaphanosoma brevireme Sars, 1901 & - & - & + \\
\hline Diaphanosoma fluviatile Hansen, 1899 & + & - & - \\
\hline Latonopsis australis Sars, 1888 & + & - & + \\
\hline Pseudosida ramosa (Daday, 1904) & + & + & - \\
\hline \multicolumn{4}{|l|}{ Anomopoda } \\
\hline \multicolumn{4}{|l|}{ Moinidae Goulden, 1968} \\
\hline Moina sp. & - & - & + \\
\hline \multicolumn{4}{|l|}{ Daphniidae Straus, 1820} \\
\hline Ceriodaphnia cornuta rigaudi Sars, 1886 & + & - & + \\
\hline Simocephalus sp. & - & - & + \\
\hline Simocephalus latirostris Stingeling, 1906 & + & - & + \\
\hline Simocephalus serrulatus (Koch, 1841) & - & - & + \\
\hline \multicolumn{4}{|l|}{ Ilyocryptidae Smirnov, 1992} \\
\hline Ilyocryptus spinifer Herrick, 1882 & + & + & + \\
\hline \multicolumn{4}{|l|}{ Macrothricidae Norman \& Brady, 1867} \\
\hline Grimaldina brazzai Richard, 1892 & + & - & - \\
\hline Macrothrix paulensis (Sars, 1901) & + & + & - \\
\hline Macrothrix squamosa Sars, 1901 & + & - & + \\
\hline Macrothrix cf elegans Sars, 1901 & + & + & + \\
\hline Streblocerus pygmaeus Sars, 1901 & + & + & - \\
\hline \multicolumn{4}{|l|}{ Chydoridae Stebbing, 1902} \\
\hline \multicolumn{4}{|l|}{ Chydorinae } \\
\hline Alonella clathratula Sars, 1896 & + & + & - \\
\hline Alonella dadayi Birge, 1910 & + & + & + \\
\hline Alonella spp. & + & + & - \\
\hline Chydorus cf sphaericus & + & + & - \\
\hline Chydorus eurynotus Sars, 1901 & + & + & + \\
\hline Chydorus nitidulus (Sars, 1901) & + & + & - \\
\hline Chydorus pubescens Sars, 1901 & + & + & + \\
\hline Disparalona leptorhyncha & + & + & + \\
\hline Dunhevedia odontoplax Sars, 1901 & + & + & + \\
\hline Ephemeroporus barroisi (Richard,1894) & + & + & - \\
\hline Ephemeroporus hybridus (Daday, 1905) & + & + & + \\
\hline Ephemeroporus tridentatus (Bergamin,1931) & + & + & + \\
\hline Acroperus harpae Baird, 1843 & - & + & - \\
\hline \multicolumn{4}{|l|}{ Aloninae } \\
\hline $\begin{array}{l}\text { Alona broaensis Matsumura-Tundisi \& Smirnov, } \\
1984\end{array}$ & + & - & - \\
\hline Alona dentifera Sars, 1901 & + & + & + \\
\hline Alona glabra Sars, 1901 & - & - & + \\
\hline Alona cf monacantha Sars, 1901 & - & - & + \\
\hline Alona guttata Sars, 1862 & + & + & + \\
\hline Alona iheringula Sars, 1901 & - & + & - \\
\hline Alona intermedia Sars, 1862 & + & + & + \\
\hline Alona ossiani Sinev, 1998 & + & + & + \\
\hline Alona sp. & + & + & - \\
\hline Alona verrucosa Sars, 1901 & + & + & + \\
\hline Camptocercus australis Sars, 1896 & + & + & + \\
\hline $\begin{array}{l}\text { Euryalona brasiliensis Brehm \& Thomsen, } \\
1936\end{array}$ & - & - & + \\
\hline Euryalona orientalis (Daday, 1898) & + & - & + \\
\hline Graptoleberis occidentalis Sars, 1901 & + & + & - \\
\hline Karualona cf karua. King, 1853 & + & + & - \\
\hline Leydigiopsis brevirostris Brehm, 1938 & + & - & - \\
\hline Leydigiopsis curvirostris Sars, 1901 & + & + & - \\
\hline Leydigiopsis ornata Daday, 1905 & + & + & + \\
\hline Nicsmirnovicus sp & - & + & - \\
\hline Notoalona sculpta (Sars, 1901) & + & - & + \\
\hline Oxyurella longicaudis (Birge, 1910) & + & - & - \\
\hline Number of species & 41 & 32 & 30 \\
\hline
\end{tabular}

species are new records for the State of Mato Grosso do Sul: Alona broanensis, Disparalona leptorhyncha, and Notoalona sculpta.

Lakes 1 and 2 presented the greatest taxonomic similarity at the species level (Figure 2).

Species richness varied substantially during the study in all three lakes, tending to be the greatest in lake 1 (Figure 3a). In this lake, species richness was high in the dry period (August) and low in the rainy period (February) during the two years of study. On the other hand, species richness was higher in February in lake 3.

The richness of species significantly correlated to dissolved oxygen concentration in lake $1(\mathrm{r}=0.57$, $\mathrm{p}=0.05)$, conductivity in lake $2(\mathrm{r}=-0.64$, $\mathrm{p}=0.05)$, and water temperature in lake $3(\mathrm{r}=0.57$, $\mathrm{p}=0.05)$.

Variations in the Shannon-Wiener Diversity Index indicated similar tendencies in lakes 1 and 2, with the lowest values in February/06 (rainy period) (Figure 3b), while there was an increase in diversity in lake 3 . For the three lakes, there was little variation in equitability during the course of the study, with high values for the three lakes, indicating low dominance of species in the three lakes (Figure 3c). Thus, variation in species richness was the factor which was most responsible for diversity index variations.

Species of the Chydoridae family were the most abundant in lakes 1 and 2, followed by Macrothricidae (Figures 4a and b). In lake 3, the Chydoridae and Daphniidae families were the most abundant taxa (Figure 4c). In lakes 1 and 2, there was a reduction in the relative abundance of Chydoridae during the summer in both years. This occurred during the increases of the Macrothricidae and Sididae abundance in lake 1 , and of the Macrothricidae abundance, in lake 2.

In lake 3, the relative abundances of Daphniidae, Macrothricidae, Sididae, and Ilyocryptidae varied irregularly during the study, with Daphniidae being more abundant than Chydoridae in August/05,

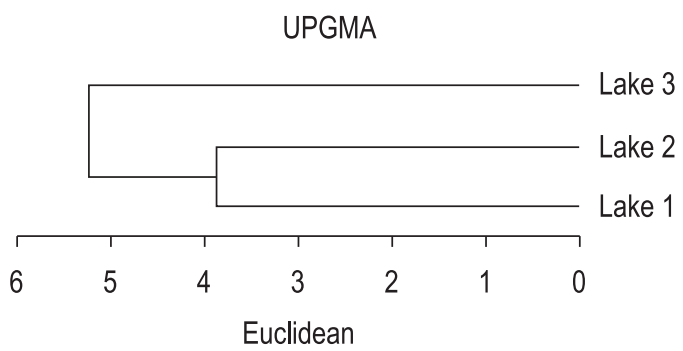

Figure 2. Cluster analysis, based on Euclidean distance, for the Cladocera species in the three marginal lakes from September/04 to August/06. 

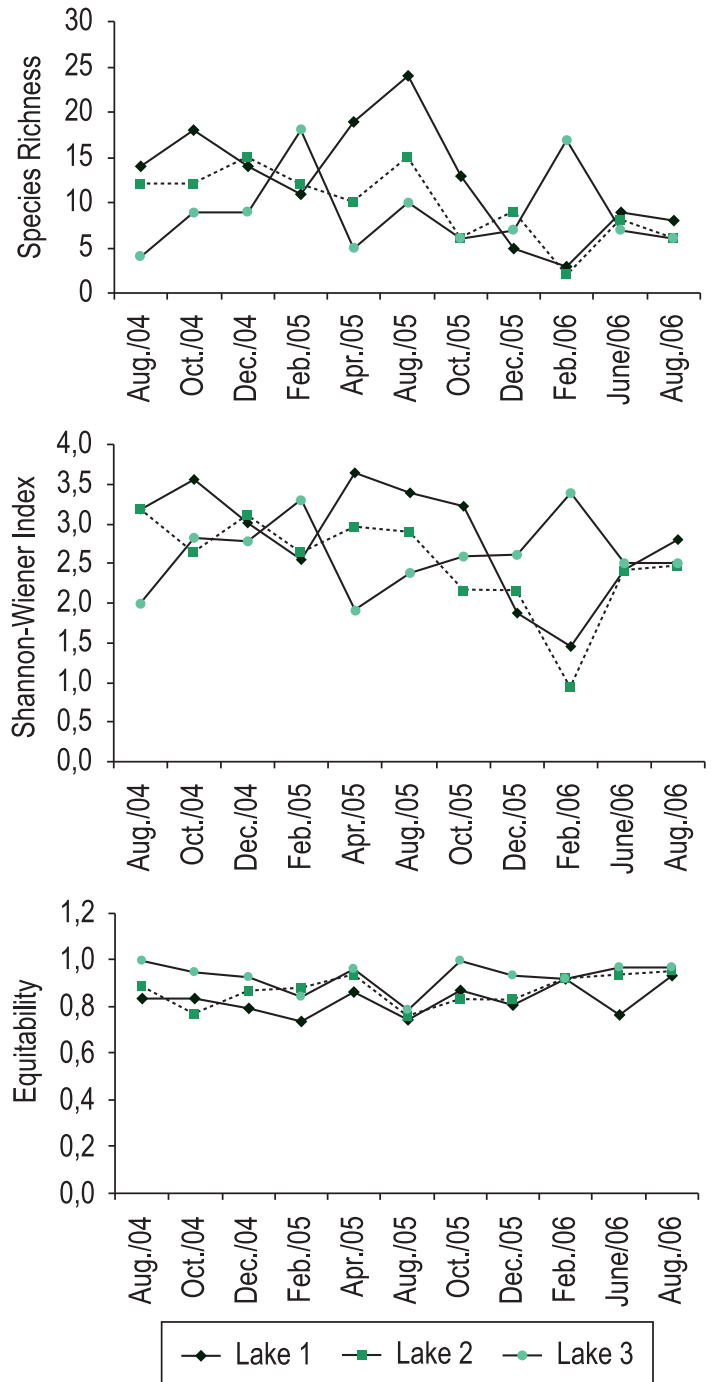

Figure 3. Temporal variation in species richness (a), Shannon-Wiener Index (b) and Pielou's Equitability (c) for the Cladocera in the three marginal lakes.

when there was no rain and the river level and temperature were very low (Güntzel et al., submitted).

The most abundant species of Cladocera in each lake are shown in Figure 5. In general, the groups of most abundant species differed between the lakes. However, only the species Macrothrix cf elegans was abundant in all lakes during the beginning of the dry period and the rainy period, while Chydorus eurynotus, in lakes 1 and 3 , seemed to be favored by dry conditions in lakes with different connectivity with the Taquari River.

As to species richness, Cladocera density was higher in lake 1 and lower in lake 3 (Figure 6). Because of the different density patterns presented by individual populations, defined temporal patterns were not observed for the total density of cladocera.
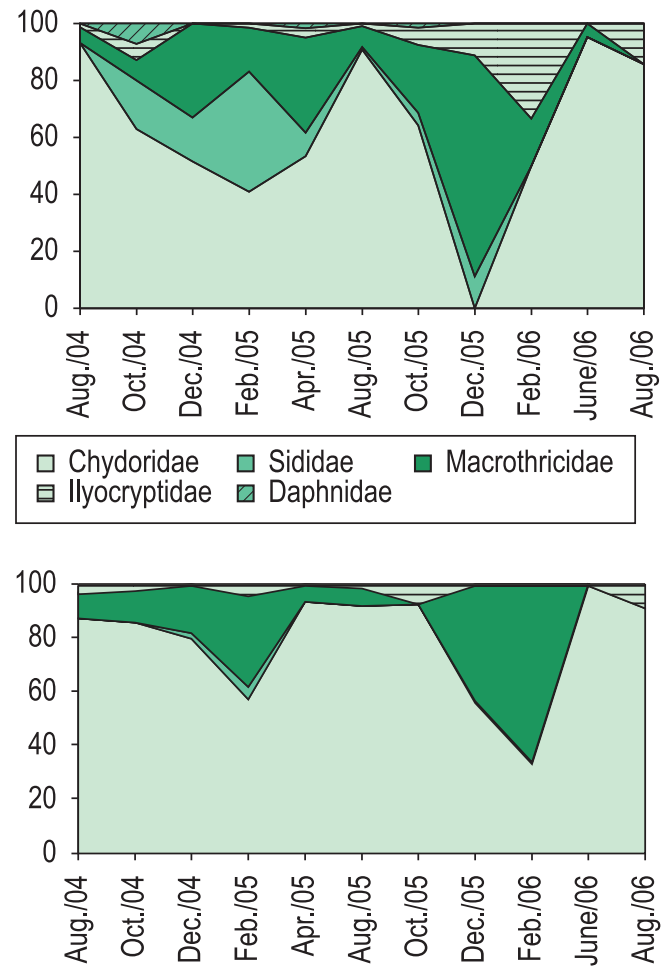

\begin{tabular}{|l|l|}
\hline Chydoridae \\
$\square$ llyocryptidae
\end{tabular}

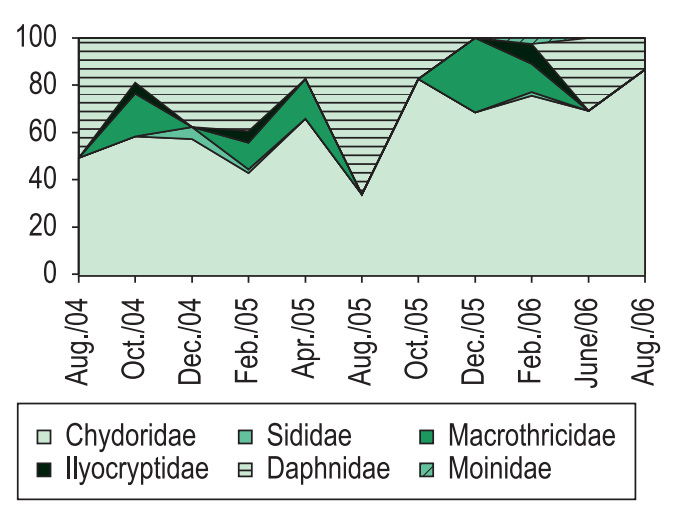

Figure 4. Temporal variation in the Cladocera relative abundance in the lakes 1 (upper), 2 (middle) and 3 (lower).

In lake 3, a significant positive correlation was found between abundance and water $\mathrm{pH}(\mathrm{r}=0.60$; $\mathrm{p}=0.05)$. No significant correlations were found between Cladocera abundance and limnological variables for the other lakes.

Temporal patterns in the distribution of the cladoceran taxa in relation to the hydrological and limnological variables were identified using Canonical Correspondence Analysis (Table 2). Best results were found for lakes 2 and 3, for which axes 1 and 2 explained around $50 \%$ of the data variance. In lake 1 , axes 1 and 2 explained $36 \%$ of the variance. 

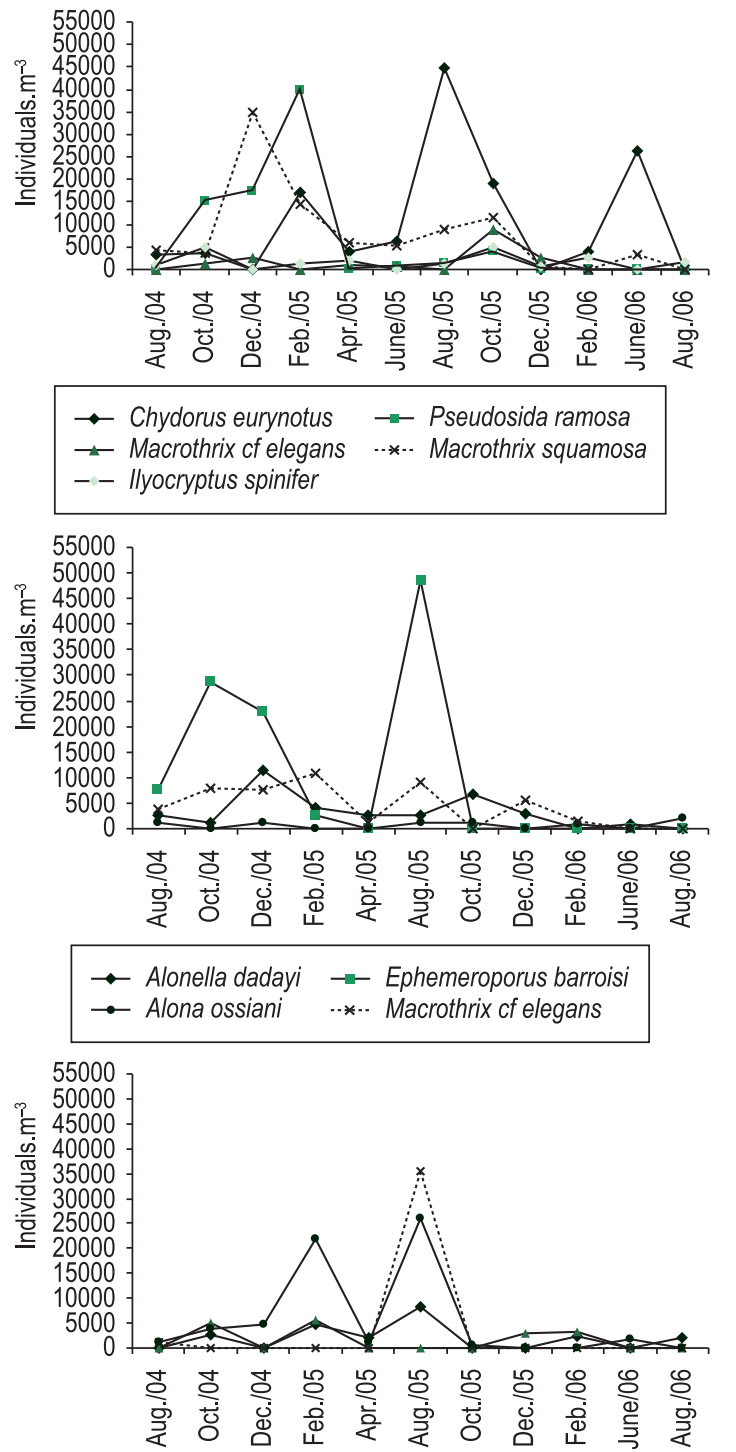

$\rightarrow$ Chydorus eurynotus $\rightarrow$ Macrothrix cf elegans

*.. Simocephalus serrulatus $\rightarrow$ Ceriodaphnia cornuta rigaudi

Figure 5. Temporal variation in density (individuals. $\mathrm{m}^{-3}$ ) of the Cladocera dominant species in the lakes 1 (upper), 2 (middle) and 3 (lower).

The canonical correspondence analysis suggested that a particularly important factor determining species distribution in lakes 1 and 3 was the seasonal variation in rainfall, modifying the nutritional characteristics (chlorophyll, nitrogen, and phosphorus) and water transparency of the lakes. However, while the same canonical correspondence coefficients were positive for lake 3 , they were negative for lake 1 . A relatively high coefficient of canonical correspondence for dissolved oxygen was observed for lake 1, but not for lake 3 .

In lake 2, the principal factors related to species distribution were changes in water transparency,

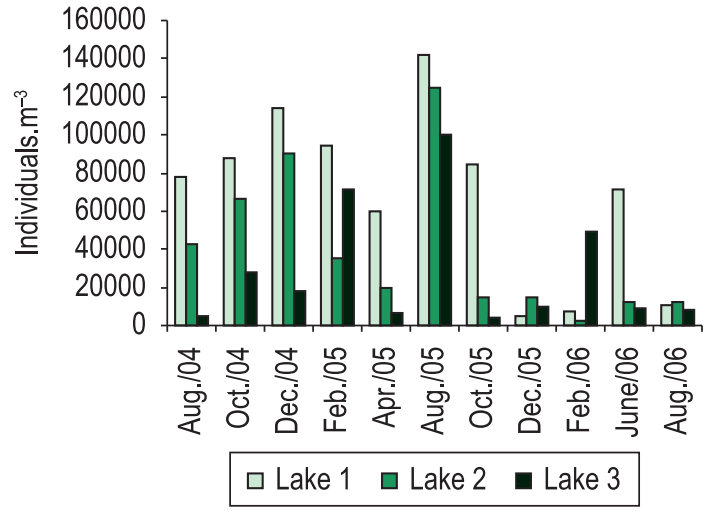

Figure 6. Temporal variation in the Cladocera density (individuals. $\mathrm{m}^{-3}$ ) in the three lake.

water temperature, concentrations of dissolved oxygen, and electrical conductivity.

\section{Discussion}

In floodplains, great biodiversity is associated with a great diversity of habitats and the preservation of the connectivity between aquatic systems (Ward and Stanford, 1995).

The number of species recorded in this study (49) is one of the highest observed for Cladocera in the Midwest region of Brazil (Neves et al., 2003; Serafim Jr. et al., 2003; Souza and Elmoor-Loureiro, 2008). The assemblages of these lakes were represented principally by the Chydoridae family, which is favored by the presence of macrophytes, as they feed principally on detritus and epiphytic algae (Smirnov, 1974).

Rocha et al. (2002) affirmed that the Chydoridae is the most important family in terms of species richness in the littoral region of lacustrine systems of the state of São Paulo, as recorded in the marginal lakes of the Mogi-Guaçu River (Wisniewski et al., 2000), where 14 of the 28 species of the recorded Cladocera species belonged to the Chydoridae family.

In the present study 34 Chydoridae taxa were found in three lakes during the two-year period; this richness is almost as high as that found by Serafim Jr. et al. (2003), demonstrating the importance of intensive sampling during the hydrological cycle.

Frequent sampling favors the recording of species with low abundance or low frequency in the environment, as is the case with the three species recorded for the first time in Mato Grosso do Sul State: Alona broaensis, Disparalona leptorhyncha and Notoalona sculpta. 
Table 2. Canonical coefficients for the Cladocera species and environmental variables in the three lakes from September/04 to August/06.

\begin{tabular}{|c|c|c|c|c|c|c|}
\hline \multirow[t]{3}{*}{ Variables/Axis } & \multirow{2}{*}{\multicolumn{2}{|c|}{$\begin{array}{l}\text { Lake } 1 \\
\text { Species }\end{array}$}} & \multirow{2}{*}{\multicolumn{2}{|c|}{$\frac{\text { Lake } 2}{\text { Species }}$}} & \multirow{2}{*}{\multicolumn{2}{|c|}{$\frac{\text { Lake } 3}{\text { Species }}$}} \\
\hline & & & & & & \\
\hline & Axis 1 & Axis 2 & Axis 1 & Axis 2 & Axis 1 & Axis 2 \\
\hline Rain volume & -3.265 & -8.957 & -0.311 & -0.307 & 0.768 & 0.801 \\
\hline River level & - & - & 0.000 & 0.000 & 0.000 & 0.000 \\
\hline Local depth & 0.000 & 0.000 & -0.301 & 1.136 & 0.581 & 0.164 \\
\hline Secchi disk & -6.037 & -12.977 & -1.836 & 0.453 & 0.018 & 0.608 \\
\hline $\mathrm{pH}$ & 2.251 & 4.447 & 0.998 & 1.875 & 0.000 & 0.000 \\
\hline Electrical conductivity & 0.000 & 0.000 & 1.131 & -0.711 & 0.342 & -1.002 \\
\hline Water temperature & -0.789 & -2.886 & -1.523 & -1.539 & -0.083 & -0.056 \\
\hline Dissolved oxygen & -1.652 & -4.593 & -1.413 & -1.402 & 0.000 & 0.000 \\
\hline Total nitrogen & 2.585 & 4.459 & 0.000 & 0.000 & -3.309 & 1.153 \\
\hline Total phosphorus & -3.039 & -6.035 & -0.970 & -0.560 & 0.159 & -0.094 \\
\hline Suspended inorganic material & -0.596 & -1.205 & 0.925 & 1.795 & 0.981 & -0.459 \\
\hline Suspended organic material & -1.076 & -1.733 & 0.000 & 0.000 & 0.000 & 0.000 \\
\hline Chlorophyll-a & 3.214 & 7.656 & 0.000 & 0.000 & -0.897 & -0.974 \\
\hline Percentage of variance & 18.812 & 17.516 & 26.789 & 24.593 & 32.572 & 17.788 \\
\hline
\end{tabular}

A. broaensis had been restricted to the reservoir of Broa in São Paulo State (Matsumura-Tundisi and Smirnov, 1984). In the present study, this species was found in lake 1, a meso-oligotrophic shallow lake containing a great development of macrophytes, which are common characteristics of the localities where $A$. broaensis has been found (Tundisi et al., 1977).

The species Disparalona leptorhyncha (identified according to Smirnov, 1992), initially identified as Disparalona acutirostris, was found in all three lakes. Notoalona sculpta was frequently found in lakes 1 and 3, but was absent from lake 2. In the Midwest region, this species was found by Elmoor-Loureiro (2007) in temporary and permanent lakes and marshes in the valley of the Paraná River (Goiás State), but had not been recorded before in Mato Grosso do Sul State.

Lakes subject to flood pulses are quite dynamic systems with two extreme conditions of dry and wet periods. Between these two periods, there are progressive changes that, according to Ward and Stanford (1995), are characterized by different degrees of connectivity between the lakes and the river channels.

Galat et al. (1997) indicates that the relative connectivity can be determined using spatial variables, morphometric parameters that quantify the connection between systems, or by temporal variables, such as frequency and duration of connection.

According to Junk (1997), environmental disturbances caused by the annual variation of the hydrological cycle are considered predictable for the floodplain community. However, this predictability is a relationship between the frequency and the duration of the connectivity and the duration of the life cycle of the organisms subjected to such disturbances.

In the present study, the degree of connectivity is related mainly to the frequency and duration of the connection between the Taquari River and the three lakes. Lake 1 has low connectivity, as the water inflow from the Taquari River occurs occasionally from local streams, in flood episodes higher than those observed in the annual hydrological cycles. Therefore, lake 1 is normally an isolated environment. Lake 2 is an intermediate system, as it receives water during the annual flood cycle of the Taquari River (monomodal pattern), and the connectivity of lake 3 is maximum (frequency and duration) in relation to the other lakes.

The disturbances imposed on Cladocera in lake 1 are predominantly associated with variations in rainfall in the drainage basin of the lake itself. Such variations can be considered predictable, since they are cyclic and can allow the recovery of the populations adapted to the dry and wet conditions alternately, ensuring the maintenance of a greater diversity of species in this environment, in comparison to the two other lakes.

Lake 1 supported the highest abundance and species richness of Cladocera associated with aquatic macrophytes. This water body had a greater development of marginal vegetation and banks of macrophytes composed of different morphological 
types, including submerged, emergent, rooted, and floating types, providing greater heterogeneity to the environment.

Concerning the temporal changes in community structure in relation to limnological variables, in lake 1 , the concentration of dissolved oxygen seemed to directly influence species richness. Because oxygen concentration is a limiting factor for species adapted to meso-oligotrophic conditions, together with other factors, it determines interruption of dormancy of zooplankton eggs, as suggested by De Stasio (1990).

Lake 2 is semi-lentic, being permanently connected to the Veados Stream, whose oligotrophic waters flow continuously into the lake. This lake is connected to the Taquari River by a narrow channel, through which the river water flows in only during the wet season. Therefore, this lake exports water to the Taquari River during most of the hydrological cycle. These conditions seem to favor the intermediate condition of richness and density of Cladocera, when compared to lakes 1 and 3.

In lake 2, the water inflow from the Taquari River results in an increase in the concentration of suspended material and makes the environment more eutrophic. Additionally, higher temperatures during the rainy season (Güntzel et al., submitted) may increase the velocity of the biological processes in this lake, whose surface is nearly covered by banks of Eichhornia azurea and Salvinia sp.

According to Thomaz et al. (2003), during flooding, the release of detritus and the decomposition of marginal aquatic macrophytes may also have contributed to the increase in conductivity in this lake. In this environment, the richness species had an inverse correlation with the electrical conductivity.

Besides the cyclic alterations associated with the rainfall regime, lake 3 is also subject to alterations caused by the constant inflow of water from the Taquari River, which drains a wide area influenced both by natural alterations and non-predictable anthropic activities. They result mainly from the farming activities in the Taquari River basin, as reported by Galdino et al. (2005).

With the river water influx, lake 3 constantly receives a greater load of inorganic material; in suspension, this material can be detrimental to Cladocerans by reducing their primary productivity and efficiency of ingestion of algae and other organic particles (Kirk, 1991).

These conditions probably do not allow for the maintenance of a high diversity and abundance of
Cladocera and may result in great disturbance of intensity and frequency, favoring the permanence of populations that tolerate such conditions better.

In contrast, the greater water flow from the river into this lake coincided with increases in richness due to the probable influx of organisms from other sub-systems. However, this situation occurred only during the rainfall peak, suggesting that maybe the species washed in did not find favorable conditions for their establishment in this lake.

The greater similarity in species composition between the lakes with the least connectivity reflects intensity of disturbances imposed on the Cladocera community in comparison to that of the lake with greater connectivity, which suffers more frequent and intense disturbances. In this lake, the smaller development of the macrophyte banks also favored species that explore open regions, as illustrated by the greater importance of Daphniidae in this environment, which may have further contributed to the dissimilarity between the lakes.

In the present study, Cladocera had distinct richness and abundance in each environment. This difference was directly conditioned by environmental variables or determined by variations that affect other groups of organisms, such as the composition and structure of macrophytes that interfere in the dynamics of Cladocera populations. However, we observe that in the studied oxbow lakes, the environmental variations conditioned by annual dry and rainfall cycles favor a greater diversity of Cladocera, since a greater connectivity with the Taquari River produces constant disturbances that are detrimental to the diversity of this group. It is probable that the negative effect of this disturbance on the diversity of Cladocera in the lake with the greatest connectivity to the river is heightened by anthropic impacts introduced by the Taquari waters.

\section{Acknowledgements}

We wish to thank Nilva Aparecida da Mota Santos for assistance with the limnological analyses and José Franscisco de Paula Filho for suggestions. This study was financed by Fundect (Foundation for the Support of Education, Science and Technology Development of the State of Mato Grosso do Sul) and $\mathrm{CNPq}$ (National Research Council).

\section{References}

ALVES, GM., VELHO, LFM, LANSAC-TOHA, F.A., ROBERTSON, B. and BONECKER, C.C. 2005. Effect of the connectivity on the diversity and 
abundance of cladoceran assemblages in lagoons of the upper Paraná river floodplain. Acta Limnologica Brasiliensia, vol. 17, no. 3, p. 317-327.

AZEVEDO, F. de and BONECKER, CC. 2003. Community size structure of zooplanktonic assemblages in three lakes on the upper River Paraná floodplain, PR-MS, Brazil. Hydrobiologia, vol. 505, p. 147-158.

BONECKER, CC., LANSAC-TÔHA, FA. and STAUB, A. 1994. Qualitative study of rotifers in different environments of the High Paraná River floodplain (MS) - Brazil. Unimar, vol. 16, no. 3, p. 1-16.

BONECKER, CC., LANSAC-TÔHA, FA. and BINI, LM. 1998. Composition of zooplankton in different environments of the Mato Grosso Pantanal, Mato Grosso, Brazil. In Anais do VIII Seminário Regional Ecologia, 1998. São Carlos: PPG-ERN-UFSCar. p. 1123-1135.

BRAAK, CJFT. and VERDONSCHOT, P.F.M. 1995. Canonical correspondence analysis and related multivariate methods in aquatic ecology. Aquatic Sciences, vol. 57, no. 3, p. 255-289.

DE STASIO, BT. 1990. The role of dormancy and emergency patterns in the dynamics of a freshwater zooplankton community. Limnology and Oceanography, vol. 35, p. 1079-1090.

ELMOOR-LOUREIRO, LMA. 2007. Phytophilous cladocerans (Crustacea, Ano mopoda and Ctenopoda) from Parana River Valley, Goiás, Brazil. Revista Brasileira de Zoologia, vol. 24, no. 2, p. 344-352.

GALAT, DL., KUBISIAK, JF, HOOKER, JB. and SOWA, LM. 1997. Geomorphology distribution and connectivity of lower Missouri River floodplain waterbodies scoured by the flood of 1993. Verhandlungen des Internationalen Vereinigung für Theoretische und Angewandte Limnologie, vol. 26, p. 869-878.

GALDINO, S.,VIEIRA, LM. and PELLEGRIN, LM. 2005. Impactos ambientais e sócio-econômicos na Bacia do Rio Taquari - Pantanal. Corumbá: Embrapa Pantanal. 356 p.

GÜNTZEL, AM., PANARELLI, EA., SILVA, WM. DA. and ROCHE, KF. Limnological conditions in the littoral zone of three oxbow lakes of the Middle Taquari River floodplain, Mato Grosso do Sul State, Brazil. In press.

JUNK, WJ. 1980. Áreas inundáveis: um desafio para Limnologia. Acta Amazônica, vol. 10, no. 4, p. 775-795.

JUNK, WJ. and SILVA, CJ. 1995. Neotropical floodplains: a comparison between the Pantanal of Mato Grosso and the large Amazonia River Floodplains. In TUNDISI, J.G., BICUDO, C.E.M., MATSUMURA-TUNDISI, T., eds. Limnology in Brazil. Rio de Janeiro: ABC/SBL, 195-218.
JUNK, WJ. 1997. The Central Amazon Floodplain: ecology of a pulsing system. Berlin: Springer Verlag, 525 p.

KIRK, KL. 1991. Inorganic particles alter competition in grazing plankton: the role of selective feeding. Ecology, vol. 72, no. 3, p. 915-923.

LANSAC-TÔHA, FA., BONECKER, CC., VELHO, LFM. and LIMA, AF. 1997. Comunidade zooplantônica. In VAZZOLER, EAM., AGOSTINHO, AA. and HAHN, NS., eds. $A$ planicie de inundação do alto rio Paraná: aspectos físicos, químicos, biológicos e sócio-econômicos. Maringá: EDUEM. p. 117-155.

LIMA, AF., LANSAC-TÔHA, FA. and BONECKER, CC. 1996. The microcrustacean fauna of a floodplain lake and a tributary of the high River Paraná, in Mato Grosso do Sul, Brasil. Studies on Neotropical Fauna and Environment, vol. 31, p. 112-116.

LIMA, AF., LANSAC-TÔHA, FA., VELHO, LFM., BINI, LM. and TAKEDA, AM. 2003. Composition and abundance of Cladocera (Crustacea) assemblages associated with Eichhornia azurea (Swartz) Kunth stands in the Upper Paraná River floodplain. Acta Scientiarum: Biological Sciences, vol. 25, no. 1, p. 41-48.

MATSUMURA-TUNDISI, T. and SMIRNOV, NN. 1984. Description of Alona broaensis sp. nov. (Crustacea: Cladocera). Hydrobiologia, vol. 113, p. 327-329.

NEVES, I., ROCHA, O., ROCHE, KF. and PINTO, AA. 2003. Zooplankton community structure of two marginal lakes of the river Cuiabá (Mato Grosso, Brazil) with analysis of Rotifera and Cladocera diversity. Brazilian Journal of Biology, vol. 63, no. 2, p. 329-343.

ODUM, EP. 1988. Ecologia. Rio de Janeiro: Editora Guanabara-Koogan.

PAGGI, JC. and JOSÉ DE PAGGI, S. 1990. Zooplâncton de ambientes lóticos e lênticos do rio Paraná Médio. Acta Limnologica Brasiliensia, vol. 3, p. 685-719.

ROCHA, CEF. and POR, FD. 1988. Preliminary comparative data on the fauna of the pleuston in the southern Pantanal, Brazil, with emphasis on the microcrustaceans. Verhandlungen des Internationalen Vereinigung für Theoretische und Angewandte Limnologie, vol. 26, p. 2137-2140.

ROCHA, O., MATSUMURA-TUNDISI, T. and TUNDISI, JG. 2002. Hot spots for zooplankton diversity in São Paulo state: origin and maintenance. Verhandlungen des Internationalen Vereinigung für Theoretische und Angewandte Limnologie, vol. 28, p. 872-876.

SENDACZ, S. 1997. Zooplankton studies of floodplain lakes of the Upper Paraná River, São Paulo State, Brazil. Verhandlungen des Internationalen Vereinigung 
für Theoretische und Angewandte Limnologie, vol. 26, p. 621-627.

SERAFIM Jr., M, LANSAC-TÔHA, FA., PAGGI, JC., VELHO, LFM. and ROBERTSON, B. 2003. Cladocera fauna composition in a river-lagoon system of the Upper Paraná River floodplain, with a new record for Brazil. Brazilian Journal of Biology, vol. 63, no. 2, p. 349-356.

SMIRNOV, NN. 1974. Fauna of the U.S.S.R: Crustacea. 1. Chydoridae. Jerusalem : Academy of Sciences of the USSR.

SOUZA, FDR. and ELMOOR-LOUREIRO, LMA. 2008. Cladóceros fitófilos (Crustacea, Branchiopoda) do Parque Nacional das Emas, estado de Goiás. Biota Neotropica, vol. 8, no. 1, p. 159-166.

THOMAZ, SM., PAGIORO, TA., PADIAL, AA. and CARVALHO, P. 2003. Decomposição das macrófitas aquáticas e sua relação com o pulso de inundação. In HENRY, R., org. Ecótonos nas interfaces dos ecossistemas aquáticos. São Carlos: Rima. p. 195-211.
TUNDISI, JG., TUNDISI, TM., ROCHA, O., GENTIL, JG. and NAKAMOTO, N. 1977. Primary production, standing-stock of phytoplankton and ecological factors in a shallow tropical reservoir (Represa do Broa, São Carlos, Brazil). In I Seminario Medio Ambiente y Represas, 1977. p. 138-172.

WARD, JV. and STANFORD, JA. 1995. Ecological connectivity in alluvial river ecosystems and its disruption by flow regulation. Regulated Rivers: Research \& Management, vol.11, p. 105-119.

WISNIEWSKI, MJS., ROCHA, O., RIETZLER, AC and ESPÍNDOLA, ELG. 2000. Diversidade do zooplâncton nas lagoas marginais do Rio MogiGuaçu: II. Cladocera (Crustacea, Branchiopoda). In SANTOS JE., PIRES, JSR., eds. Estudos integrados em ecossistemas: Estação Ecológica de Jataí. São Carlos, Rima. p. 559-586.

Received: 18 September 2009 Accepted: 17 June 2010 